\section{Intersections}

Canadian Journal of Music

Revue canadienne de musique
Intersections CANADIAN JOURAL OF MUSIC
REVUE CANADIENEE DE MUSIQUH

\title{
Miniatures and tensions: phenomenological reverberations in and around Kaija Saariaho's Lichtbogen (1985-86)
}

\section{Anne Sivuoja-Gunaratnam}

Volume 25, numéro 1-2, 2005

Northern Perspectives on Music and Culture

URI : https://id.erudit.org/iderudit/1013305ar

DOI : https://doi.org/10.7202/1013305ar

Aller au sommaire du numéro

Éditeur(s)

Canadian University Music Society / Société de musique des universités canadiennes

ISSN

1911-0146 (imprimé)

1918-512X (numérique)

Découvrir la revue

Citer cet article

Sivuoja-Gunaratnam, A. (2005). Miniatures and tensions: phenomenological reverberations in and around Kaija Saariaho's Lichtbogen (1985-86).

Intersections, 25(1-2), 44-66. https://doi.org/10.7202/1013305ar
Résumé de l'article

Cet article étudie les miniatures dans le Lichtbogen de Kaija Saariaho, pour neuf musiciens et électronique en direct (1985-86). Le matériel utilisé pour la recherche est composé d'enregistrements, de la partition, d'entretiens avec la compositeure et différents articles portant sur l'oeuvre et sa périphérie. Du point de vue méthodologique, cette recherche s'articule autour de la phénoménologie de Bachelard (La Poétique de l'espace) et de la " spectromorphologie » de Denis Smalley. Les miniatures sont de subtiles constellations spatio-temporelles qui exigent une stratégie d'écoute non globale ou une " loupe auditive " afin de bien les percevoir. Dans le cas de Saariaho, ces miniatures sont souvent imprégnées d'une tension musicale qui se reflète dans l'ensemble des matériaux musicaux et textuels. En évoluant à la frontière de la musique et du langage, elles remettent en question la notion de séparation stricte entre le musical « pur » et l'extra musical.
Copyright @ C Canadian University Music Society / Société de musique des universités canadiennes, 2005
Ce document est protégé par la loi sur le droit d'auteur. L'utilisation des services d’Érudit (y compris la reproduction) est assujettie à sa politique d'utilisation que vous pouvez consulter en ligne.

https://apropos.erudit.org/fr/usagers/politique-dutilisation/ 


\section{Miniatures and Tensions: Phenomenological Reverberations in aNd around Kaija SaAriaho's LICHTBOGEN (1985-86)}

Anne Sivuoja-Gunaratnam

This article studies miniatures in Kaija Saariaho's Lichtbogen (1985-86). These forms present themselves as very concise musical spaces imbued with Bachelardian phenomenological reverberations. The miniature forms of Lichtbogen are of interest not only due to their extreme subtlety, rendering them almost imperceptible, but also because of 'tensions' embedded in them. As well as in the work itself, miniatures can also be traced in Saariaho's statements concerning the piece and in her musical thinking in general. Therefore, in the course of this article we will examine not only selected fragments of Lichtbogen, but also the composer's spoken and written texts. These texts interact with the work's miniature forms, creating phenomenological reverberations situated on the border between the so-called purely musical and the extra-musical. The methodology used to study Lichtbogen takes issue with the globalizing approach of traditional analysis. My intention is neither to present a complete examination of the work's form nor to disclose some low common denominator or "deep structure" to which all of the miniatures of this composition could be reduced. Rather, I wish to present an alternative approach, which appears more appropriate for the study of this and perhaps other music of the late twentieth century.

\section{Kaija Saariaho's Miniatures and the Phenomenology OF GASTON BACHELARD}

Lichtbogen (1985-86) is the composer's first piece in which she combined live-electronics with a live ensemble. Since its premiere in 1986, it has been performed often and several different recordings are now commercially available (cf. bibliography). The strings (21111) and flutes (flute in C, piccolo, or alto flute in $\mathrm{G}$ ) are amplified, and electronic reverb and harmonizer, typical of Saariaho's live-electronic pieces (including NoaNoa or Près) are required. ${ }^{1}$ The harmonizer modifies the pitch level of these instruments up to a $1 / 4$ tone. The relative reverb and harmonization values (in procents) are indicated in the score. No reverb or harmonization is applied to the piano, harp or percussion instruments (vibraphone, marimba, xylophone, glockenspiel, crotales, bass-drum and suspended cymbal). (Kankaanpää 1996a, 103-5.) 
Lichtbogen begins with an F-sharp drone lasting approximately two minutes (bars 1-41, see bars 25-28 in Example 1). Simon Emmerson $(1998,160)$ characterizes it as "Klangfarbenmelodie on F\#." The flute sound is soon joined by the contrabass producing the F-sharp as a natural harmonic and thereafter by the violins and viola. The sustained F-sharp remains in a constant state of fluctuation. Both colour and pitch are continuously modified due to the spectral differences of the instruments. This transition within the pitch space (Sivuoja-Gunaratnam 1998,539 ) is reinforced by adding more instruments, all of which have slightly different spectra, attacks and reverberation times. These differences are increased further by changes to the amount of vibrato, as well as to bowing and articulation, which slides between normal, sul tasto, and sul ponticello (Iitti 1993, 49-51). The frequent changes in bowing are gradually transformed to tremolos, which increase the noise (Kankaanpää 1996a, 105-6) in the micro-world contained within F-sharp. In fact, a parametric reversal takes place between timbre and pitch, because the pitch level is produced by the very materiality of instrumental timbres. ${ }^{2}$ At first, it might be difficult to perceive these differences as musically meaningful because our ears have been pre-tuned for listening to pitches and pitch patterns rather than events that occur within a pitch. The opening of this work invites the listener to retune his or her ears so as to prepare them for the subtle differentiations of Saariaho's musical miniatures.

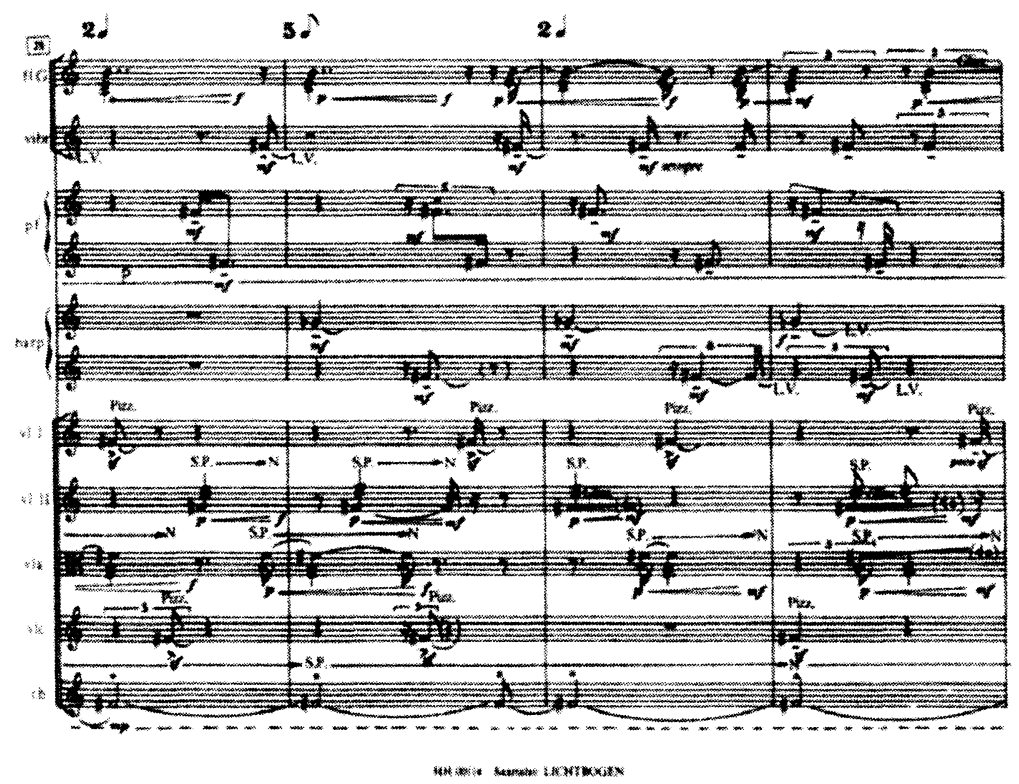

Example 1. Lichtbogen; bars 25-28. Copyright @ 1986 Edition Wilhelm Hansen Helsinki AB. Reprinted by Permission. Printed with permission of Edition Wilhelhm Hansen AS, Copenhagen.

2 Previously, for instance in Vers le blanc (1982), Verblendungen (1982-84), and Jardin secret I (1984-85), Saariaho $(1991,1987 a)$ has been keen on exploring the parametric fusion of harmony and timbre (Kankaanpää 2005, 85-105; Iitti 2005, 131-32). 
In an interview dated a few years after Lichtbogen was finished, Saariaho (Bacon 1988, 10) expressed her interest for minimal size spaces:

I remember having read in Goethe's Theory of Colours something about the transitional states between light and shade. There was something that inspired me enormously, in the same way as an extreme slowing down of speech, just when the vowel turns to a consonant, the transitional state between them. This transition is slowed down to the extreme, the transition that usually is so tiny that we wouldn't even notice it. There is something significant.

The F-sharp in the beginning of Lichtbogen is not without tension. On the contrary, the tensional aspect is based on the opposition between "pure" and "noisy" sound qualities, a typical means by which Saariaho creates tension at various levels of musical form. For her, noisy sounds are breathing, the breathy sound of a flute in low register, or bowing sul ponticello. Pure sounds are bells or the human voice singing in the Western tradition (Saariaho 1987a: 93-97). In the F-sharp drone the pure sounds would be intonations of that pitch within the regular spectral structure of each instrument, whereas noise is produced by breathing, sul ponticello, or frequent bowing (Iitti 1993, 10-12; Kankaanpää 1995, 226-27; Sivuoja-Gunaratnam 1998, 538-39; on noise versus pure sound see also Smalley 1997, 120-21).

The remarkable beginning of Lichtbogen and Saariaho's own statements on the work's subtle tensional states led me to explore further the idea of miniature in this piece and to examine the tensions generated within these structures. In Saariaho's music these two are often intertwined. My research material consists of the following sources:

- sound recordings

- the score

- authorial prefaces

- public and private epitexts

Following terminology developed by Gérard Genette (1987, 182-218), the composer's programme notes written for concerts and recordings are authorial prefaces because they provide information directly related to how the work was composed, its main constituent elements, how it should be interpreted and the title. These prefaces are produced in a variety of formats including the Internet (Saariaho 1987c). Public epitexts are those which circulate around the other sources in the form of radio and television interviews, newspaper columns, lectures, etc. (Genette 1987, 316-18). Private epitexts include correspondence as well as discussions and interviews not originally intended for publication (Genette 1987, 341-70). In this research project all of these sources are considered because I am interested in identifying possible interconnections, or so-called phenomenological reverberations (Bachelard 1969, xviii-xx). These interconnections surface as tensional miniatures in various types of texts of different materiality (musical sound, written music, language, image). The term "phenomenological reverberation" refers to the capacity of a single poetic image to condition the awakening of a creative consciousness in the reader. Through its 
power and freshness, the image generates a reverberation that opens up new ways of perceiving and understanding for the actively participating reader (Bachelard 1969, xix).

Methodologically, this research project is based on Gaston Bachelard's classic, The Poetics of Space (1969 [1958]), which studies space and spatiality in the French phenomenological tradition using literary texts as the source material. The content of the book is divided according to different spaces and bears titles like "House and Universe," "Nests," "Shells," "Corners," "Miniature," and "Intimate Immensity." The last two chapters are important for this study because they present sensitive perspectives on the inherent multiplicity of the space contained within the miniature.

Emmerson (2001, 41-44) first led me to read Bachelard for the purpose of better understanding Saariaho's music. He connected "intimate immensity" to a passage in Jardin secret II (1986) for harpsichord and tape and thus posed the question of the applicability of Bachelard's phenomenology to this music in even greater detail. Bachelard's notions of water, oceans and imagination have already been applied to Saariaho's Amers (1992) (Humphreys 1998, 96-111). ${ }^{3}$ Lichtbogen seemed to be an ideal case for a more elaborate test of the Bachelardian approach because it presents various kinds of miniatures and other spatial phenomena in the composition, as well as in the texts surrounding it.

Denis Smalley's concept of spectromorphology (1997) can be viewed as phenomenological in its attitude. This analytical method is based on aural perception: "spectro" refers to sound and morphology to its shape and structure. Spectromorphology identifies the audible structures of sound shapes and traces their evolution in time with a refined set of descriptive terms. Prior knowledge of how the music has been made or what electronic devices were utilized is excluded. The method is intended to provide the active listener with tools that enrich the listening experience. It is mainly envisaged for electronic music, but it can be applied with ease to conventionally notated instrumental music. In fact, one of the composers Smalley suggests is Saariaho (Smalley 1997, 109).

By emphasizing the listening experience over the technical analysis of the scores and connections with sonic environments outside the piece proper, Smalley's method critically embraces the idea of reduced listening put forward by Pierre Schaeffer (1977 [1966], 261-78; Smalley 1997, 111). Schaeffer's method is explicitly phenomenological as can be seen in his references to the work of Maurice Merleau-Ponty and particularly Edmund Husserl's concept of "époché" (Schaeffer 1977, 263-70), that is to say, bracketing out the world situated beyond the immediate act of perception.

\section{The Aurora Borealis and Spatial Continuity}

From the point of view of the work's genesis, understanding this composition from the perspective of the miniature might appear ill-advised, because

3 I thank Martá Grabócz for bringing this Mémoire de maîtrise, prepared under her supervision, to my attention. 
Saariaho's authorial preface written for the United Kingdom premiere (13 May, 1987) frames the listening experience in cosmic dimensions.

The name Lichtbogen stems from Northern Lights which I saw in the Arctic sky when starting to work with this piece. When looking at the movements of these immense, silent lights, which run over the black sky, first ideas concerning the form and language for the piece started to move in my mind. Which is the dependence-and does it exist at all? - between this phenomenon of nature and my piece, I don't know (Saariaho 1987c; 1987d).

In this authorial preface Saariaho discloses her source of inspiration for the piece and explains the background concerning her choice of title. Titles are particularly important for her compositional process because they help to bring her musical material into focus (Beyer 2000,308). They refer to the content of the individual piece, rather than to a genre, and are thus "thematic" (Genette $1987,78-82$ ). Saariaho states that "it [the title] belongs to the music in some way" (Beyer 2000, 308). The language in which the title is written is also significant. Obviously, listeners are not able to grasp the composer's private meanings but, like other authorial information (epitexts), titles do inevitably evoke associations and interpretations. Paraphrasing Bachelard, one can say that a phenomenological reverberation exists between the music, the title and the northern lights. The idea of immense and limitless space, implicit in the phenomenon of the northern lights, offers a loose, culturally shared frame within which the musical events of Lichtbogen may be projected.

As a title, Lichtbogen bears reference both to the piece and to events prior to the compositional process. According to Martá Grabócz (1993, 157 and 164) the shape of the northern lights had an impact on Lichtbogen's global form, as can be seen in Saariaho's sketch (example 2). The German title of the piece does not refer precisely to northern lights (aurora polaris or aurora borealis should be translated as Polarlicht or Nordlicht). There is no explicit geographical reference; the title rather reinforces the connection to light. In fact, the term "Bogen" reverberates with aurora borealis because one of the forms of this phenomenon is called an auroral arc.

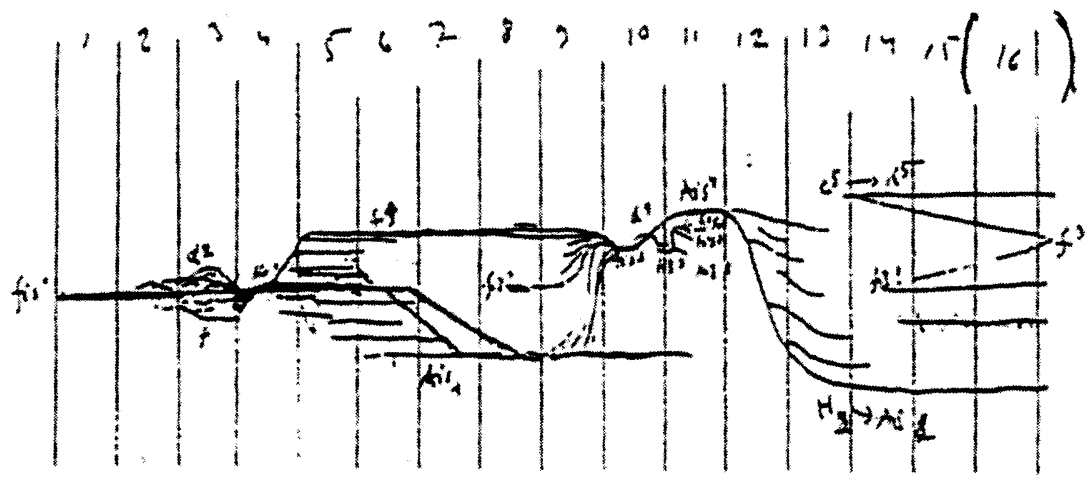

Example 2. Sketch for Lichtbogen (Grabócz 1993, 164). 
The northern lights are a relatively common phenomenon in the cosmos but are perceived rather rarely because normally they can only be seen near the magnetic poles, which cover a small section of the Earth's surface. In the Northern Hemisphere, they are visible in the northern parts of Canada, Russia, and Scandinavia as well as in Iceland and the southern part of Greenland (Jussila 2002, 82). In the Southern Hemisphere there are very few places suitable for observing the southern lights or aurora australis because that magnetic pole is situated in the Southern Sea (Antarctic Ocean). The North, then, functions as a gateway to this cosmic spectacle. From a more southern perspective, the northern lights and North in general may appear exotic as well.

While having a genetic connection to the North, Lichtbogen is in many respects also a very French piece. Its compositional technique is close, though not identical to musique spectrale and the repertoire associated with the ensemble L'Itinéraire. ${ }^{4}$ The analysis of the sound material was executed at IRCAM, in the very heart of the French contemporary music. Furthermore, Lichtbogen was commissioned by the French Ministry of Culture and was first performed by the French ensemble 2e2m (conductor Georges-Elie Octos) in Paris on 23 May 1986 at the Centre Pompidou. The work is dedicated to Paul Méfano, a French composer and also the honorary president of the $2 \mathrm{e} 2 \mathrm{~m}$. Whereas the north/south tension is diluted when the piece is played in the North, it certainly marked the work's genesis and first performance, both of which took place in the South (that is to say, where the northern lights are not visible).

The Cosmos and the natural sciences have long been a source of interest for Saariaho (1987b). Besides Lichtbogen, many of her titles refer to the Cosmos and other natural phenomena: Io (1987), Solar (1993), Orion (2002), Jardin secret I-II (1985-86), Il pleut (1986), Nymphea (1987), Petals (1988), Six Japanese Gardens (1993), Trois rivières (1994) Colours du vent (1998), Cloud Music (1997), Neiges (1998), Sept papillons (2000), and Asteroid 4179: Toutatis (2005). ${ }^{5}$ While working on Lichtbogen, she was drawn to the writings of Hubert Reeves (b. 1932), particularly Poussières d'étoiles (first published in 1984), which introduced the notion of cosmic temporality, celestial geography and the birth of life on a more general level. Saariaho (1987b) found both the text and the images fascinating. The chapter on the aurora borealis contains a photograph of the phenomenon taken not from Earth but from space (Reeves [1984] 1994, 114-21).

The aurora borealis is caused by a process created by the Sun. Solar wind spreads plasma and particles into space and in so doing extends the Sun's

4 L'Itinéraire was founded in 1973 by the composers Michaël Levinas, Tristan Murail, Hugues Dufourt, Gérard Grisey and Roger Tessier and has since become one of Europe's leading contemporary music ensembles.

5 An unpublished piece also exists dating from Saariaho's student years entitled Aurora for flugelhorn, trombone, percussion, piano and guitar (1979). 
magnetic field to that of the Earth. As these fields interact, solar particles pass into the ionosphere and collide with its particles. The transfer of energy at the particle level creates the visible phenomenon we recognise as the northern lights. The principal colours are green, red and blue and the shapes are often classified as arcs, bands, spirals, curls, corona and other more diffuse forms. The density of this cosmic material can vary enormously. The phenomenon has a normal duration of between one and six hours, though it can last longer (Jussila 2002, 112-22; Reeves 1994, 114-21).

Another aspect of time and space to be taken into account when admiring auroras is the fact that it takes approximately eight minutes for light to travel from the Sun to the Earth. Thus in terms of temporality the Sun and Earth exist on two irrevocably different phases. According to Reeves $(1994,83)$, during the Middle Ages it was believed that the Cosmos consisted of two separated layers: the celestial and the terrestrial. Whereas the stars and the sky were considered eternal, the Earth was bound to continuous change. Today of course this binary understanding of the Universe is not scientifically valid. Nevertheless, this vision remains present in colloquial thought and has perhaps left traces in Lichtbogen too.

In many instances the work's texture is simultaneously divided into two layers, which are distinguished by their timbre (Iitti 1993; 69-81; Kankaanpää 1996a, 131). These layers or fields interact in various ways in the course of the piece. The terminology for describing the textural quality of these layers as grainy or smooth stems from Saariaho's own texts (1987a; 1991) and coincides with her conception of sound (pure sound vs. noise). According to Saariaho $(1987 \mathrm{a}, 94)$ :

[i]n an abstract and atonal sense the sound/noise axis may be substituted for the notion of consonance/dissonance. A rough, noisy texture would thus be parallel to dissonance, whilst a smooth, clear texture would correspond to consonance.

It is however important to understand that noise or noisy texture should not be regarded as a supplement to pure sound or smooth texture. Noise is not a negative term nor does it occupy the position of a "special effect"; its aesthetic status is equivalent to that of pure sound (Sivuoja-Gunaratnam 1998, 538; see also Nuorvala 1991, 5-6; Iitti 1993, 11-13). Saariaho's classification of the sounds and textures is her own, though it can be compared to those of other composers. Since the advent of electroacoustic music, one of the central compositional parameters of contemporary music has been the axis pure sound vs. noise. This axis is also important for the composers of the musique spectrale (Smalley 1997, 120).

Smalley employs the term "streaming" to describe a musical texture consisting of at least two different spectromorphological layers. This term can be usefully applied to the smooth and grainy sound layers in Lichtbogen (example 3 ). On the one hand, the glockenspiel, piano and harp form the smooth layer 
with a bright, colourful sonority and the texture is made up of a kind of soft, "flock-like" sound quality, which designates a collective motion of numerous small and even micro-musical gestures. On the other hand, the flute and strings oscillate between a noisy granular texture and hard, bright sound qualities. The granular quality of the string parts is reinforced by adding pressure to the bow and playing sul ponticello, as well as by the application of electronic amplification and harmonization (Smalley 1997, 117; Iitti 1993, 42-43). Within both layers, gradual or "proximate" transformations of sound (Smalley 1993, 293) predominate. Rather than violent breaks and juxtapositions of sharply contrasting textures, proximate transformations are characterised by continuous, incremental change, in which a connection to the preceding state is preserved (Smalley 1993, 287). As a result, changes in sonic identity occur in slow motion, creating a sense of continuous spatiality rather than one of temporality. The writing of each instrumental part (examples 1 , 3 and 5) shows how Saariaho avoids regular repetition, thus enhancing a kind of sensuous minimalism in both textural layers. ${ }^{6}$

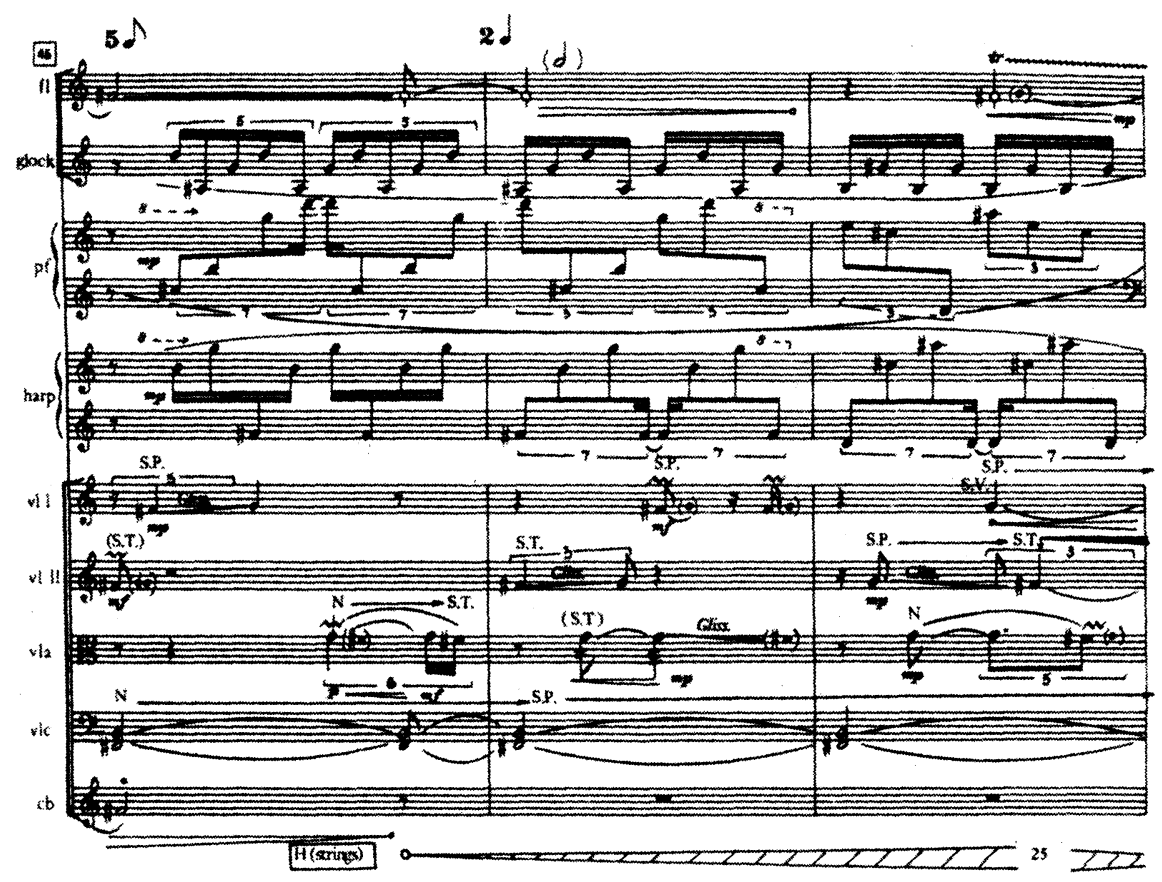

Example 3. Lichtbogen; bars 45-50. Copyright (c) 1986 Edition Wilhelm Hansen Helsinki AB. Reprinted by Permission. Printed with permission of Edition Wilhelhm Hansen AS, Copenhagen.

6 I thank Henry Bacon for suggesting that Juhani Pallasmaa's term, used to describe architecture, could be applied to Saariaho's music (Pallasmaa 2002). 


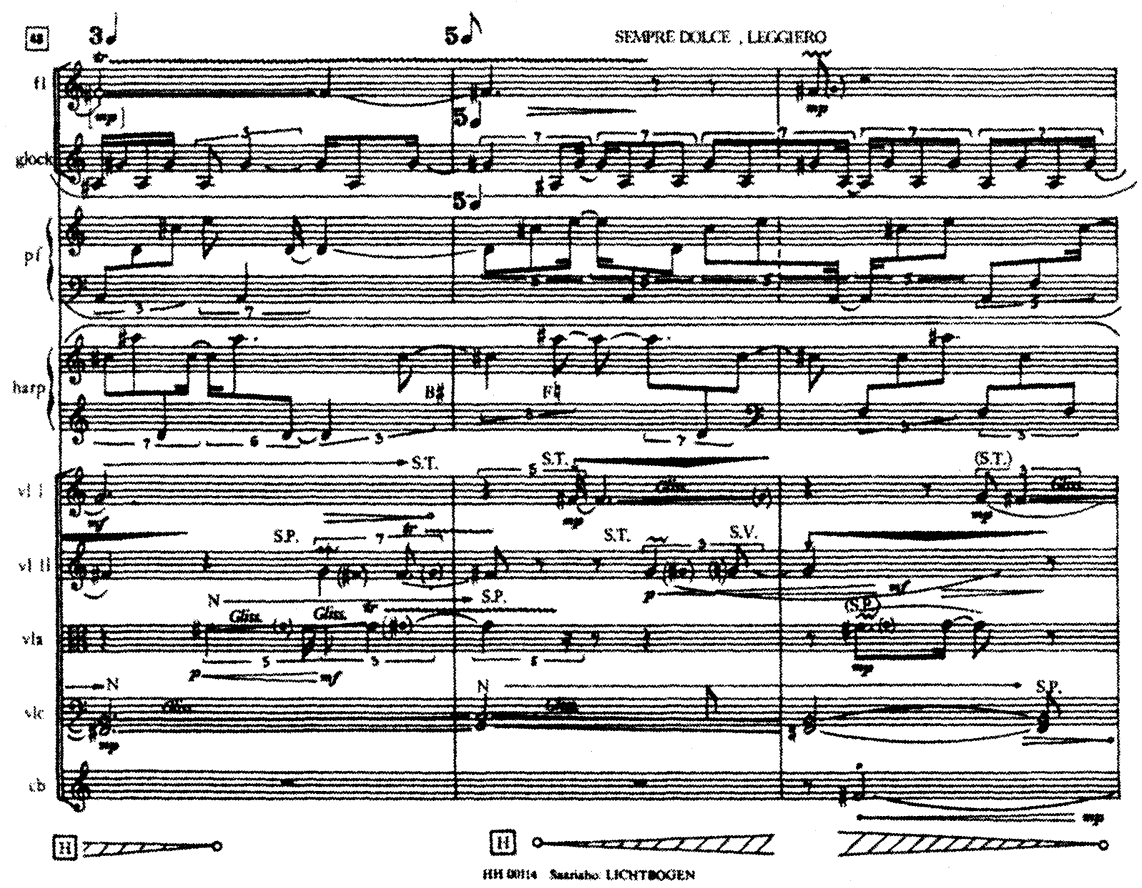

Example 3. (cont'd)

\section{Miniatures and Magnifications}

When contemplating the northern lights one is struck by the enormous disproportion of magnitude among its constituent elements. Minuscule particles emanating from a huge source (the Sun) must travel vast distances. These particles, or "stardust," are present throughout the solar system and seem to form a connective tissue linking large planetary bodies. ${ }^{7}$ These facts reverberate with Bachelard's phenomenology, which postulates that the extremely small is intimately related to the infinitely large.

It would seem, then, that it is through their "immensity" that these two kinds of space-space of intimacy and world space-blend. When human solitude deepens, then the two immensities touch and become identical" (Bachelard 1969, 201, 172, 189).

The beginning of Lichtbogen (example 1) is certainly not the only instance of miniature but it is structurally the most prominent because of its location.

7 Whereas the Moon is covered in a layer of this "stardust," the Earth is protected by its magnetic field (Reeves 1994, 120). 
It functions as a kind of aural magnifying glass ${ }^{8}$ that allows the listener to hear a single pitch as a source of multiple musical gestures. The magnification is accomplished through the slowing down, repetition and concentration of musical events, and consists of numerous attacks, vibratos, glissandi, trills, tremolos, and dynamic changes produced by various instruments with different physiological properties. According to Gaston Bachelard $(1969,158)$, " $[t]$ o use a magnifying glass is to pay attention, but isn't paying attention already having a magnifying glass? Attention by itself is an enlarging glass."

In the following I will present two additional cases of miniature forms and their magnifying function in Lichtbogen, which are very different in nature. The first focuses on the principles of harmonic construction and the second on the amplification of the flutist's whispers. Clearly, these cases do not exhaust Lichtbogen's miniature forms but are concrete examples of the musical material and thought which constitute this work.

On at least two occasions, Saariaho (1987a, 129-30; 1991, 436, 441-44) has explained how the harmonic structures for Lichtbogen are based on a few recorded cello strokes (example 4). There are basically two kinds of sounds: First, the pure sound of a sustained harmonic is broken down by increasing pressure on the bow and by moving it toward the fingerboard (example 4a); and second, glissandi from one harmonic to another (example $4 \mathrm{~b}$; see also Kankaanpää 1996a, 130). She was particularly interested in the microscopic space between the two artificial harmonics where, for a fraction of time, the sound disappears (Linjama 1987, 114). These short events were recorded and different phases of the sound specimens were subsequently analyzed at IRCAM. The noise (due to added bow pressure) and multiphonics contained in the samples became part of Lichtbogen's harmonic structure, occasionally producing micro-intervals, audible particularly in sections with slow tempi (Saariaho 1991, 441; Kankaanpää 1996, 128-33 and 2005, 92-97).

(a)

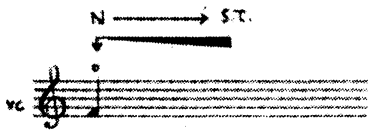

(b)

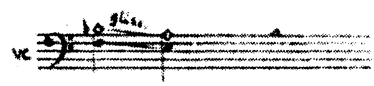

or

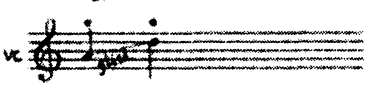

Example 4. Cello sounds analyzed by Saariaho in order to obtain material for Lichtbogen's harmony (Saariaho 1987b, 129).

8 With regard to Saariaho's music, Kankaanpăa (1996a, 128-29; 2005, 92-93) uses the term "acoustic microscope", referring to a technique employed by composers of musique spectrale, in which a single tone is projected in time and space to form textural and harmonic structures. Heiniö (1995, 460) uses the term "microscope of timbre" to designate the technical resources offered through the electronic manipulation of sound in Saariaho's compositions. 
The procedure comes close but is not identical to those used by the French composers of musique spectrale and associated with the ensemble L'Itinéraire (Gérard Grisey, Tristan Murail, or Hugues Dufourt), where a spectrum of a sound can serve as the basis of a large scale harmonic structure (Pousset 1994, 31; see also Baillet 2000, 5-20, 39-45; Cohen-Levinas 1993). Saariaho has shown little interest in instrumental synthesis typical of spectral composers, and therefore has used the results of her analysis only as raw material, which she modifies during the compositional process (Saariaho 1991, 436; 1987a, 129-30; Linjama 1987, 114; Kankaanpää 1996a, 128-37 and 2005, 92-97). In her work, Saariaho shapes sound to suit her aesthetic project and rejects the demands of naturalism.

And yet, Saariaho has also been fascinated by the idea of generating harmonic structures on the basis of the very material of music, the sound (Cohen-Levinas 1991, 18). In a text written soon after the composition of Lichtbogen she expressed her interest in finding similarities between microcosmos and macro-cosmos (Saariaho 1987b). According to Bachelard (1969, 151-53), miniatures typically generate macro-level phenomena. He observes that " $[t]$ his nucleizing nucleus is a world in itself. The miniature deploys to the dimensions of the universe. Once more, large is contained in small" (Bachelard 1969, 157).

In Lichtbogen, the short cello transitions were used to generate a large-scale harmonic universe that cannot be apprehended in an instant but only in the passing of time. Indeed, the connection between the micro-level and macrolevel lies beyond immediate observation, even that of the composer, were it not for her analytical and technical tools, which functioned as aural magnifying glasses. The division between inside and outside appears to be interchangeable here, as the harmonic structures of a few singular sounds are used in the harmonic construction of the entire piece. According to Bachelard (1969, 211-12), the dialectics of inside and outside prevail in logic and (analytical) philosophy but can, or rather should, be overcome through the power of imagination.

In Lichtbogen, instruments are occasionally amplified; a practice typical of Saariaho's works involving live-electronics. This allows her to use sounds that would otherwise escape the ear (Cohen-Levinas 1991, 24). In this case, amplification functions as a kind of aural magnifying glass. One of the most dramatic points of the piece occurs at the entrance of the text towards the end of the composition (example 5). Without modifying the balance between instruments through the forceful amplification of the flute part (Emmerson $1998,161)$, the phonemes whispered into the alto flute and the flutist's breathing sounds would remain inaudible. The phonemes are extracted from the French translation of a poem by Henry Vaughan (1622-95), entitled The World (1655); particularly from its first line: "J'ai vu l'éternité l'autre nuit"[I saw Eternity the other night] (Saariaho 1987b; Iitti 1993, 80, 86-89). The words have been intentionally fragmented in such a way that it is hardly 
possible to understand the semantic content (Saariaho 1987b). The electronic reverb (marked $R$ in the score) extends the passage in time and space and blends the sounds into a simultaneous whole (cf. Riikonen 2005, 317-22 for detailed analysis of this passage). In other words, the "phonetic phenomena and phenomena of the logos harmonize" (Bachelard 1969, 198).

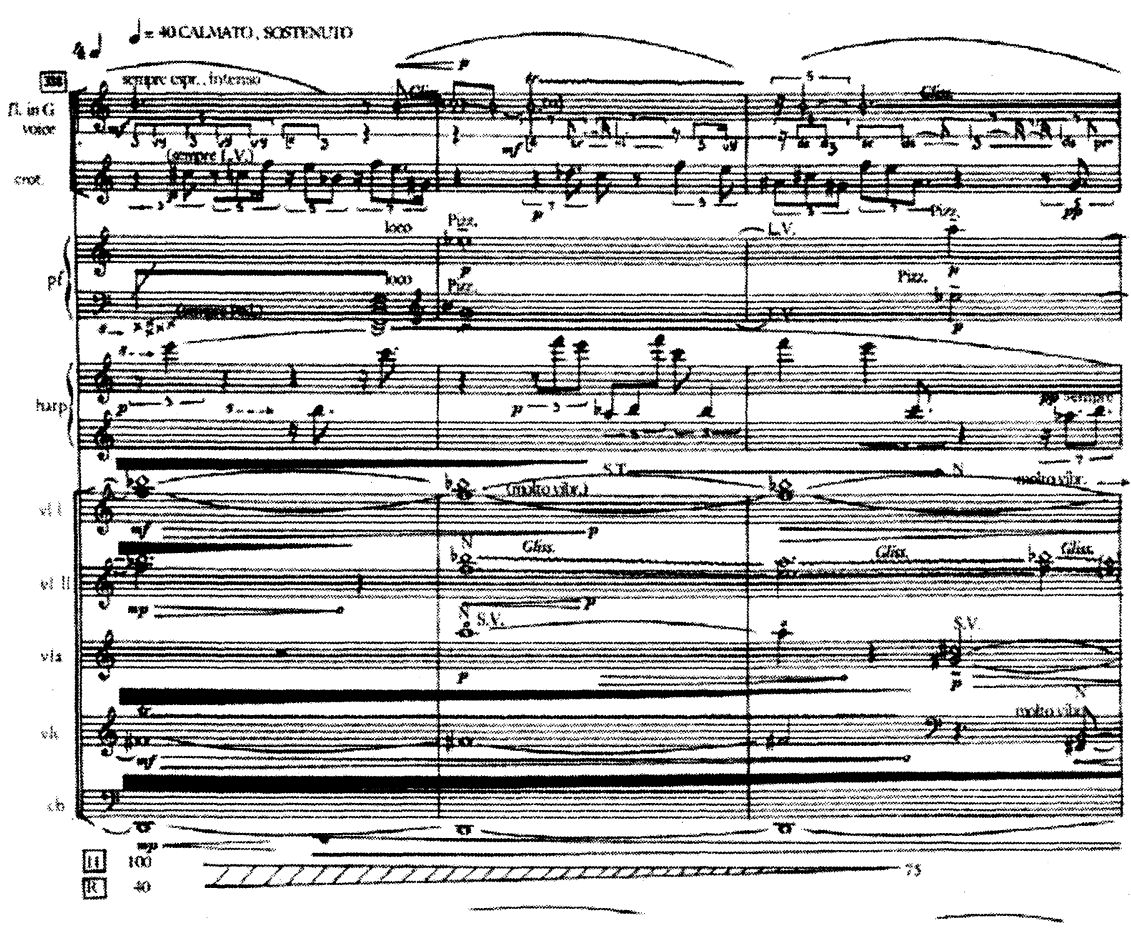

Example 5. Lichtbogen; bars 338-40. Copyright @ 1986 Edition Wilhelm Hansen Helsinki AB. Reprinted by Permission. Printed with permission of Edition Wilhelhm Hansen AS, Copenhagen.

That Saariaho inserted lines from Vaughan's poem into a composition, inspired by the northern lights, is certainly no coincidence. At the time she found the poem, the compositional process was nearly finished. Only the ending had yet to be written, and this poem seemed to contain what was needed.

The poem grants access to a dazzling view of endless light, space: beneath the light, peace and eternity, the time passes on as hours, days, years. I was surprised when I found the poem, because its atmosphere was exactly what I wanted to express in my piece (Saariaho 1987b).

In the poem, eternity is juxtaposed with a speaking subject (in the first person), representing a measurable conception of time. This juxtaposition is analogous to the medieval separation of the celestial and the terrestrial presented above and generates the particular tension of Vaughan's text. A similar tension also prevails 
in Lichtbogen, with its obvious allusion to cosmic spectacle. Furthermore, the piece begins by focusing on the musical micro-worlds contained within a pitch and ends with an evocation of eternity. The very act of enunciating eternity is accomplished through the most intimate of means: a whisper. Amplification and reverberation transmit not only the whisper but also the sounds of the flutist's tongue and subtle transformations within his or her oral cavities, one of the most intimate human spaces (Riikonen 2003, 111-14 and 2005, 317-22; Sivuoja-Gunaratnam 2003, 78-79).

\section{Tension ON THE Limen 9}

Saariaho's interest in transitional spaces was originally aroused through her contact with the visual arts, and particularly Goethe's Theory of Colours. The theory plays an important role in Rudolf Steiner's pedagogy (Kupiainen 1981) and, as a former student of the Steiner school (Moisala 1994, 229), Saariaho was obviously acquainted with the theory's main points.

The plastic arts have allowed me to grasp the importance of transitional spaces. Even as a child I was fascinated by the idea proposed by Goethe in his Theory of Colours (1810), which places the birth of colours within the confines of light and shade (Saariaho 1987a, 97).

While studying in Paavo Heininen's composition class at the Sibelius Academy, Saariaho attended a guest lecture by the Finnish architect, Juhani Pallasmaa. Among the issues raised in his lecture was the idea of creating liminal spaces invested with tension. Saariaho returned to this concept in one of her own lectures, given at the Sibelius Academy some twenty years later, demonstrating the impact Pallasmaa's ideas have had on her development (Saariaho 1998a).

Another important point of reference for Saariaho and her concept of liminal spaces is the music of the French spectral composers, particularly Gérard Grisey (Michel 1994, 9; Beyer 2000, 304). Saariaho visited Darmstadt in the early 1980s, at a time when Grisey's music was being given considerable attention. Continuous processes, transitions, and metamorphoses are typical for Grisey's aesthetic vocabulary, just as modeling sounds and textures on the basis of spectral analysis constitutes an important aspect of his compositional technique (Baillet 2000, 47-93). In his 1982 Darmstadt lecture entitled "La musique: le devenir du son," Grisey (1984) crystallized his aesthetic principles. One of the central terms was "liminal", referring to borderlines over which musical parameters interact and become ambiguous. This comes close to Saariaho's idea of transitional spaces (Saariaho 1987a, 97): "The tensions created by transitional spaces fascinated me most of all as parameters with which it was possible to create musical forms." However, Grisey's concept of

9 The term "limen" refers to the threshold between an imperceptible and a perceptible sound stimulus. 
the liminal does not contain the tensional element, which often is central to Saariaho's musical textures; this is exemplified in Lichtbogen. In the following I will present a few examples in which the concept of the liminal occupies a pivotal role. I will refer to the musical examples presented above and will now place emphasis on their tensional aspect.

The cello sounds used by Saariaho $(1987 a, 129-30 ; 1991,441)$ for creating harmonic structures for Lichtbogen can be regarded as an example of transitional space. By adding pressure to the bow, the cellist transforms pure sound into noise (example 4a). Example 5 presents another case of tensional element applied to liminal space. The phonemes whispered by the flutist into the instrument form larger units, from which it is of course impossible to grasp the semantic content of the verses extracted from Vaughan's poem. Tension is engendered because the listener is suspended "on the limen" between understanding and not understanding semantic content. One finds a similar tension between intelligible and unintelligible speech in Saariaho's radiophonic piece entitled Stilleben (1988) in which taped speech is one of the main compositional materials (Kankaanpää 1996a, 62-63). ${ }^{10}$ This sort of relationship has been common in electronic music since Karlheinz Stockhausen's Gesang der Jünglinge (1955-56) (Ernst 1977, 88-90).

The last example concerns the micro-interval space between two tones, a relevant issue for musique spectrale (Grisey 1984, 21). Micro-intervals are typical for pieces written in the spectral idiom because the approximate frequency values obtained from spectral analysis cannot be emulated by diatonic scales. Micro-intervals inhabit the miniature space within a diatonic step, and when used often, contribute to the breakdown of diatonicism. But in Lichtbogen, the micro-intervals are not the only means to go beyond diatonicism: the frequent glissandi and "harmonized" sounds are also situated in the pitch-space beyond diatonicism. This tension between diatonic and non-diatonic writing also involves timbre; as mentioned above, in Lichtbogen only the strings and flute produce micro-intervals and non-gradational glissandi, and harmonization is only applied to the sounds produced by those particular instruments (cf. also Kankaanpää 1996a, 103-4). In example 1, the use of micro-intervals and non-gradational glissandi (cf. the strings and flute in example 3) combine to produce a fluctuating pitch level, creating a tensional relationship within the diatonic pitch space. The micro-intervals surrounding the exact pitch level F-sharp can be understood either as its fluctuating, subtly out of tune extensions of diatonic pitch (the diatonic listening mode) or as forming new pitch intervals around F-sharp (non-diatonic, micro-interval listening mode). According to Smalley (1997, 120):

10 A recording of Lichtbogen, together with other recorded sounds (airplane, trains, subway, as well as singing and speaking voices), is embedded in Stilleben (Kankaanpää 1996b; Sivuoja-Gunaratnam 2005b). 
if there is no intervallic relationship with another pitch, the pitch-attribute becomes a background factor. ... Even with a pitch-drone, the actual pitch ... is unimportant if intervallic pitch relationships are absent.

Obviously, in electro-acoustic music a pitch may be significant as such, building patterns and relationships with other pitches (Smalley 1997, 119). In that case, where attention is focussed on external relationships, spectral properties such as timbre are secondary. More common are internal relationships, which focus on micro-interval patterns within a given pitch, as exemplified by the beginning of Lichtbogen. However even here the F-sharp retains musical value as a pitch, and this value reverberates beyond its immediate context because it returns at structurally pivotal positions (Iitti 1993, 52-53, 69-70). This can be seen also in one of Saariaho's sketches. Note how the F-sharp (marked "fis") returns at sections 8,10 and 14 in the sketch for Lichtbogen (example 2). Thus the articulation of F-sharp is significant from both perspectives (as a site of internal and external focus), though its external value can only be apprehended retrospectively as the piece progresses.

\section{REVERBERATING SilenCES}

In Lichtbogen there are a few musical entities that are perhaps even subtler than the miniatures discussed above. Silences reverberate across the music, as well as the authorial epitexts and prefaces, and therefore obtain phenomenological value. On more than one occasion, Saariaho (1987c; 1987d) has stated that both the visual spectacle and the silence of the cosmic phenomenon inspired her to hear music from within. Indeed one could say that in Lichtbogen she composed the silence she saw. For Vladimir Jankelévitch $(2003,140)$, music is a form of silence:

Music, which is in itself composed of so many noises, is the silence of all other noises, because as soon as music raises its voice, it demands solitude and insists that it occupy space alone, excluding other sounds.

Saariaho's reference to silence is intriguing, because at the time she wrote Lichtbogen her music contained little explicit silence (Sivuoja-Gunaratnam 2005a). In a private interview, Saariaho (1998b) explained that cutting music to bring forth silence was much more violent than any other musical gesture and stressed that she had to force herself to do it. Before the composition of ...à la fumée (1990), placing silence within a piece was unthinkable because she was afraid that her music would not last to the other side. Even when she forced herself to use silence, it

$\{\ldots\}$ felt like leaping over an abyss; it felt horribly long; is there anyone who can endure it? But there was a need to find a place for silence within music, and until then it just had not been possible (Saariaho 2002). 
Before the composition of ...à la fumée, musical textures were characteristically spatial in the sense that they contained very little forward motion and linear writing. The idea of a void in a space such as the sea or the Cosmos requires an effort of imagination. In this context, Saariaho's taboo with regard to silence is understandable: the lack of silence in her work before 1991 can thus be seen as a direct consequence of aesthetic decisions concerning compositional technique and style.

The continuity of the sonic events is taken to the extreme in Lichtbogen. As mentioned above, the music often unfolds in terms of streaming and proximate transformations. However, besides the two compulsory silences that frame the piece, at the beginning and end (on framing silences, see Lissa 1964, 445-46; Littlefield 2001, 63-66), the work contains one explicitly marked (possible) silence. There are also examples of quasi silences and an imaginary silence which is related to the genesis of the piece.

In fact, Lichtbogen does not start with the F-sharp drone but with the breath of the flutist, marked unambiguously in the score (Kankaanpää 1996a, 106). This sound is scarcely audible, though in concert performances the visual cues of the conductor and the flutist's movements do draw the listener's attention to it. Just as the piece seems to emerge out of nowhere, it ends symmetrically by gradually dissolving into nothing. In the last bars, the amplified harmonics of the two violins are marked morendo and then al niente; the same occurs in the contrabass with its D drone (bars 355-57). Both the flute sound and the whistle tone produced by the flutist reach for al niente. At both the beginning and the end, short sections of music pivot on the tensional limen between the audible and inaudible. The music lingers on the absolute and compulsory threshold of its framing boundaries. A similar moment takes place once within the piece, at the pivot (bars 40-41), where the F-sharp drone connects to the next section and then disappears. Musical continuity is ensured by a fragile harmonic tone (F-sharp) in the contrabass. All three of these quasi silences are "hardly perceptible" in Jankélévitch's (2003, 142-43) sense: "On the border of the material and immaterial, of the physical and transphysical, the almost-nothing designates minimal existence, beyond which would be non-existence, nothing pure and simple."

Lichtbogen contains one explicit silence marked by an apostrophe at approximately the middle of the piece (example 6). Note how Saariaho placed the pause outside rather than within the staves. The musicians must decide what kind of temporal value, if hardly any at all, they will afford the pause. And yet again, the silence is covered by the (im)perceptible bass drum appearing from al niente and sliding towards $p p p$ and pppp. This subtle, (almost) silent moment divides Lichtbogen into two halves, a typical formal procedure in Saariaho's work, which in this case indicates a textural change because there is no continuity through proximate transformation between the two parts. A similar instance of textural non-continuity can also be found between bars 167 and 168, though here no explicit silence is indicated. It is 

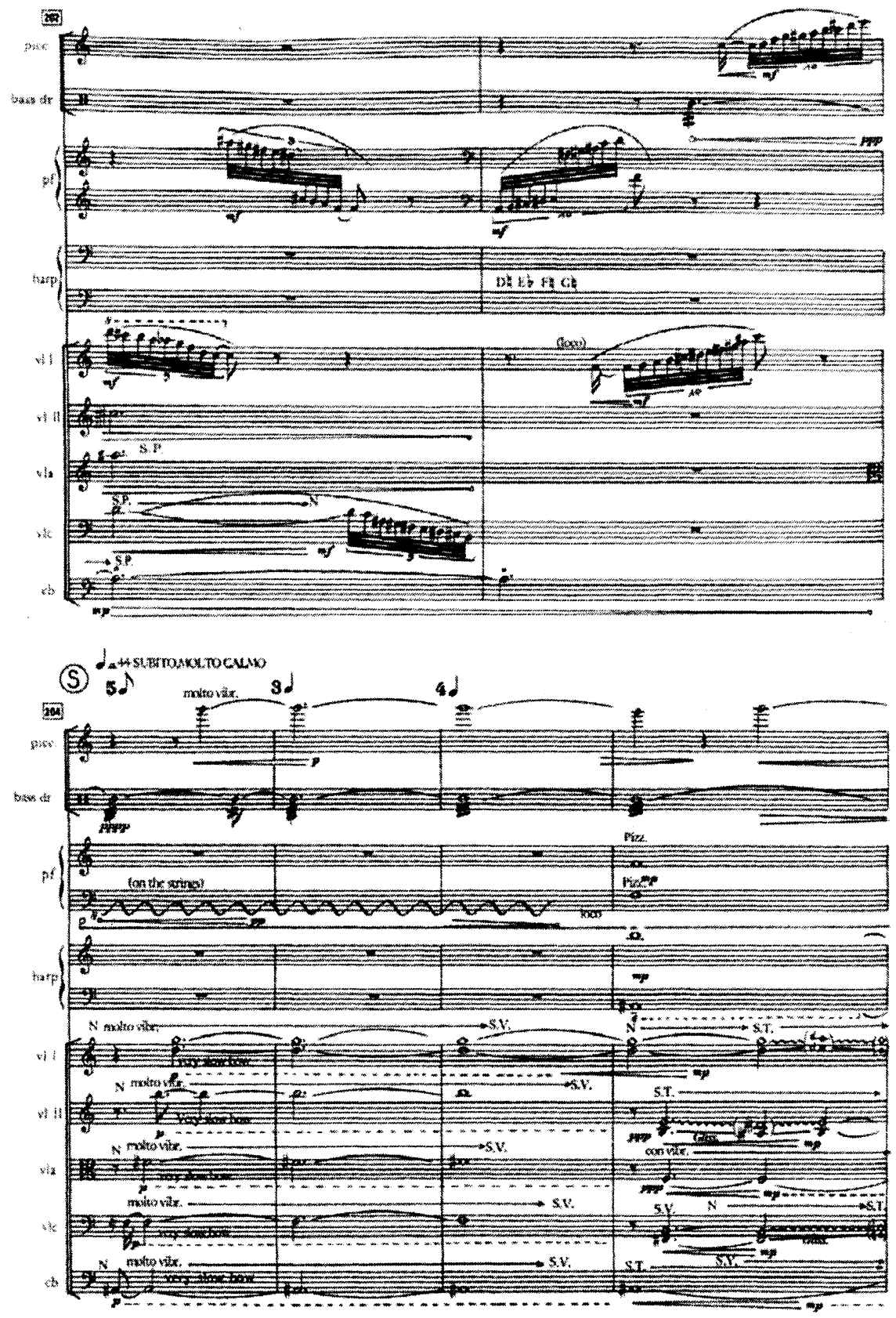

Example 6. Lichtbogen; bars 202-207. Copyright @ 1986 Edition Wilhelm Hansen Helsinki AB. Reprinted by Permission. Printed with permission of Edition Wilhelhm Hansen AS, Copenhagen. 
intriguing to imagine a connection between the two quasi-silences in the middle of the piece and the cello gestures (example 4), which served as one of the points of departure for the entire work. After all, Saariaho was particularly interested in that minuscule silent space, which occurs in the transition between two harmonics.

\section{Concluding Remarks}

In the course of this article, we have investigated the phenomenological reverberations formed in tensional miniatures, which surface both in Lichtbogen and in the texts around this music. As mentioned at the outset, this approach entails the abandonment of the globalizing approach of traditional analysis. Consequently, no attempt has been made either to examine the possible spatial structure of Lichtbogen as a whole or to fix a place for miniatures within this broader context. On the contrary, a single poetic image and its versatile occurrences have provided sufficient material for a detailed examination of the phenomenological reverberations in and around Lichtbogen. Rather than disclosing a possible deep structure for "the miniature," to which all singular instances of it would be reduced, my intention has remained in tune with Bachelard's $(1969, \mathrm{xxi})$ endeavour.

But there is even less hope of attaining to a synthetic phenomenology which would dominate an entire oeuvre, as certain psychoanalysts believe they can do. It is therefore on the level of detached images that I shall succeed in "reverberating" phenomenologically.

But how far should one push such a project? Where do these reverberations end? My pragmatic limit has been to focus on what surfaces in my primary research material. For example, this study has avoided interpreting Saariaho's music in terms of marginality and femininity, which are contrasted with large-scale, so-called masculine forms of composition (Välimäki 2001; 2003; Kallberg 1996, 40-45, 144-45). Such an interpretation is certainly possible and relevant, but not necessarily indispensable for understanding the significance of miniatures in Saariaho's music and musical thought. Rather than surfacing voluntarily in her writings, the topic of femininity is constantly being projected onto both (Moisala 1994 and 2000). Indeed, as my research concentrated on connections between the music and the composer's statements, there would not have been much to work with within the chosen methodological frame because the authorial epitexts contain little reverberation with regard to gender.

In order to avoid possible misunderstandings, it must be stressed that I am not suggesting that Lichtbogen is a miniature or that sections of Lichtbogen are miniatures, but that it contains-along with several of Saariaho's texts-moments or constellations, which I find worth investigating as miniatures. Tracing phenomenological reverberations in miniatures obviously leaves many unanswered questions pertaining to Lichtbogen. Other analysts have 
taken a more global approach and the reader is cordially invited to consult their work for more information on this extraordinary composition (Grabócz 1993; Iitti 1993; Smalley 1993, 293; Kankaanpää 1996a, 128-137; Emmerson 1998, 159-61; Kankaanpää 2005). That being said, I would also stress that the purpose of analysis is not to exhaust the work but rather to thoroughly examine the research objective.

According to Bachelard $(1969,161)$, miniatures have a consoling power:

Miniature is an exercise that has metaphysical freshness; it allows us to be world conscious at slight risk. And how restful this exercise on a dominated world can be! For miniature rests us without ever putting us to sleep. Here the imagination is both vigilant and content.

Miniatures challenge not only our sensual perception but also our imagination (Bachelard 1969, 166-67), and they offer novel ways in experiencing spatiality in music. By tracing miniatures in the music (sound recordings and score) and also in the title and authorial prefaces, as well as in interviews and other epitexts, the borderline between language and music, between what is "inside" and "outside" the work suffuses as tensional miniatures reverberate and pass through material borders.

\section{REFERENCE LIST}

Bachelard, Gaston. 1969 [1958]. The Poetics of Space, trans. Maria Jolas.

Boston: Beacon Press. NB. The Finnish translation of Bachelard's book (2003) was used in the research. However, in the article, all the references and quotes refer to the English edition (1969). . 2003. Tilan poetiikka, trans. Tarja Roinila. Helsinki: Nemo.

Bacon, Henry. 1988. "Musiikkia valon ja varjon rajamailta." Rondo 2: 8-10. Baillet, Jérôme. 2000. Gérard Grisey. Fondements d'une écriture. Paris: L'Harmattan.

Beyer, Anders. 2000. "Kaija Saariaho: Colour, Timbre, Harmony". The Voice of Music. Conversations with Composers of Our Time, ed. and trans. Anders Beyer and Jean Christensen. Aldershot: Ashgate, 301-15.

Cohen-Levinas, Danielle ed. 1991. "L'Itinéraire." La revue musicale 421-24. 1993. "Entretien avec Kaija Saariaho." Les cahiers de l'ircam 2 (La synthèse sonore): $13-41$.

Emmerson, Simon. 1998. "Acoustic/Electroacoustic: The Relationship with Instruments." Journal of New Music Research 27(1-2): 146-64. . 2001. "The Electroacoustic Harpsichord." Contemporary Music Review 20/1: 35-58.

Ernst, David. 1977. The Evolution of Electronic Music. New York: Schirmer Books.

Genette, Gérard. 1987. Seuils. Paris: Éditions du Seuil. 
Grabócz, Márta. 1993. "La musique contemporaine finlandaise: Conception gestuelle de la macrostructure, Kaija Saariaho et Magnus Lindberg." Les Cahiers du CIREM (Centre international de recherches en esthétique musicale). 26-27 (Musique et geste), 155-68.

Grisey, Gérard. 1984. "La musique: le devenir du son." Darmstädter Beiträge zur Neuen Musik 19: 16-23. Also published in 1991 Revue musicale 421-22-23-24: 291-300.

Heiniö, Mikko. 1995. Suomen musiikin historia 4: aikamme musiikki. Porvoo: WSOY.

Humphreys, Linda. 1998. Le phénomène aquatique: un modele de composition et un objet sonore pour des compositeurs $d u X X^{e}$ siècle. Parallèle dे un essai de Gaston Bachelard. Mémoire de maîtrise, Département de musique, Université des Sciences Humaines de Strasbourg, photocopy.

Iitti, Sanna. 1993. "Mutta tämähän on maisema, madame Saariaho!" Kaija Saariahon Lichtbogen. Tutkielma, Sävellyksen ja musiikinteorian osasto, Sibelius-Akatemia, photocopy.

. 2005. "Sukupuolen merkitys Kaija Saariahon säveltaiteessa." Elektronisia unelmia. Kirjoituksia Kaija Saariahon musiikista, ed. Anne SivuojaGunaratnam. Helsinki: The Helsinki University Press, 125-50.

Jankélévitch, Vladimir. 2003 [1983]. "Music and silence." Music and the Ineffable, trans. C. Abbate. Princeton: Princeton University Press, 130-55.

Jussila, Jouni. 2002. Aurora. Revontulien taivaallinen näytelmä. Porvoo: WSOY.

Kallberg, Jeffrey. 1996. Chopin at the Boundaries. Sex, History and Musical Genre. Cambridge: Harvard University Press.

Kankaanpää, Vesa. 1995. "Sointivärin käsite musiikin kuvaajana. Kaija Saariahon sointivärikäsitykset ja niiden ilmeneminen soolohuiluteoksessa Laconisme de l'aile." Musiikki 3, 218-48.

. 1996a. Sointivärin organisaatio Kaija Saariahon 1980-luvun sävellyksissä. Lisensiaatin tutkielma, Turun yliopisto, musiikkitiede, photocopy. . 1996b. "Displaced time: transcontextual references to time in Kaija Saariaho's Stilleben." Organised Sound 1/2: 87-92.

. 2005. "Sointivärin ja harmonian suhteet Saariahon varhaissävellyksissä." Elektronisia unelmia. Kirjoituksia Kaija Saariahon musiikista, ed. Anne Sivuoja-Gunaratnam. Helsinki: The Helsinki University Press, 85-105.

Kupiainen, Marjo. 1981. Goethen väriopin lähtökohtia. $2^{\text {nd }}$, revised edition. Helsinki: Suomen antroposofinen liitto.

Linjama, Jyrki. 1987. "Kaija Saariaho - säveltäjä värien, valon, visuaalisuuden voimakentässä." Synteesi 6/4: 110-17.

Lissa, Zofia. 1964 [1962]. "Aesthetic Functions of Silence and Rests in Music," trans. E. Tarska. The Journal of Aesthetics and Art Criticism 22/4: 443-54. Littlefield, Richard. 2001. Frames and Framing. The Margins of Music Analysis. Acta Semiotica Fennica XII. Imatra: International Semiotics Institute. 
Moisala, Pirkko. 1994. "Kaija Saariaho - naissäveltäjästä säveltäjäksi." Musiikin toinen sukupuoli, Pirkko Moisala \& Riitta Valkeila. Helsinki: Kirjayhtymä, 227-34.

. 2000. "Gender Negotiations of the Composer Kaija Saariaho in Finland: Composer as Nomadic Subject." Music and Gender, ed. Pirkko Moisala and Beverley Diamond. Urbana and Chicago: University of Illinois Press, 166-88.

Nuorvala, Juhani. 1991. Kaija Saariaho in profile, transl. Timothy Binham. Helsinki: Finnish Music Information Centre. Published also http://www.fimic.fi/ >Contemporary Music>Composers $>$ Kaija Saariaho $>$ Profile and Articles (31 January 2006).

Pallasmaa, Juhani. 2002. Sensuous minimalism. [s.1.]: China Architecture \& Building Press.

Pousset, Damien. 1994. "La transparence du signe." Compositeurs d'aujourd'hui: Kaija Saariaho, ed. Risto Nieminen. Paris: IRCAM, 25-42.

Reeves, Hubert. 1994 [1984]. Poussières d'étoiles. Nouvelle édition. Paris: Éditions du Seuil.

Riikonen, Taina. 2003. "Shaken or Stirred - Virtual Reverberation Spaces and Transformative Gender Identities in Kaija Saariaho's NoaNoa for flute and electronics." Organised Sound 8/1: 109-15.

.2005. "Tarinoita suusta: puhumisen ja kuiskimisen asuttamia huilistiidentiteettejä." Elektronisia unelmia. Kirjoituksia Kaija Saariahon musiikista, ed. Anne Sivuoja-Gunaratnam. Helsinki: The Helsinki University Press, 295-329.

Saariaho, Kaija 1986. Lichtbogen for nine musicians and electronics. Copenhagen: Wilhelm Hansen.

. Jukka-Pekka Saraste \& Avanti!, Finlandia FACD 374 (1989) and Finlandia Records 3984-23407-2 (1999).

. John Whitfield \& Endymion Ensemble, Finlandia Records FACD 361

(1989) and Finlandia Records 3984-23407-2 (1999).

- Lorraine Vaillancourt \& Nouvel Ensemble Moderne. Ummus UMM102 (1990).

. Hannu Lintu \& Avanti!, Ondine, ODE997-2 (2002).

. 1987a. "Timbre and harmony: interpolations of timbral structures." Contemporary Music Review 2/1: 93-133.

. 1987b. "Kielen ja äänen synteesit." Helsingin Sanomat 14 July.

. 1987c. "Program note on Lichtbogen." http://www.fimic.fi/>Contem-

porary Music $>$ Composers $>$ Kaija Saariaho $>$ List of Works $>$ Lichtbogen;

http:// www.chester-novello.com $>$ Composers $>$ Saariaho $>$ Large Chamber Ensemble> Lichtbogen

1987d. "Program note on Lichtbogen, 9 March, Helsinki." Helsinki Biennale, 3-11.

. 1991. "Timbre et harmonie." Le timbre, métaphore pour la composi-

tion, ed. Jean-Baptiste Barrière. Paris: Christian Bourgois, 412-53. 
. 1997. "Matter and Mind in Music." Matter and Mind in Architecture, ed. Pirkko Tuukkanen. Helsinki: The Alvar Aalto Foundation/The Alvar Aalto Museum, 11-115.

. 1998a. "Musiikki ja väri: solisti ja laboratorio." Guest lecture at Sibelius Academy, 26 February. Photocopy of Saariaho's lecture notes.

. 1998b. "An unpublished interview by Anne Sivuoja-Gunaratnam."

Helsinki 3 July.

. 1999. The Musical World of Kaija Saariaho. PRISMA CD-ROM. Por-

voo: WSOY.

. 2002a. "Kaija Saariahon säveltäjäilta. An interview by Olli Koskelin."

Radio 1, The Finnish Broadcasting Company, 7 September.

Schaeffer, Pierre. 1977 [1966]. Traité des objets musicaux. Essai Interdiscipline.

Nouvelle édition. Paris: Seuil.

Sivuoja-Gunaratnam, Anne. 1998. "Rhetoric of Transition in Kaija Saariaho's

Music." Musical Signification: Between Rhetoric and Pragmatics. Proceedings of the 5th International Congress on Musical Signification, ed. Gino Stefani, Eero Tarasti \& Luca Marconi (eds.). Bologna: CLUEB, 537-42. . 2003. "Desire and distance in Kaija Saariaho's Lonh". Organised Sound 8/1: 71-84.

. 2005a. "Hiljaisia hetkiä Kaija Saariahon musiikissa." Musiikin estetiikka ja filosofia, ed. Alfonso Padilla and Juha Torvinen. Helsinki: The Helsinki University Press, 397-429.

. 2005b. "Rihmasto, chaosmosis ja Saariahon Stilleben (1988)." Elek-

tronisia unelmia. Kirjoituksia Kaija Saariahon musiikista, ed. Anne Sivuoja-Gunaratnam. Helsinki: The Helsinki University Press, 203-26.

Smalley, Denis. 1993. "Defining Transformations." Interface 22/4: 279-300. . 1997. "Spectromorphology: explaining sound-shapes." Organised Sound, 2/2: 107-26.

Välimäki, Susanna. 2001. "Subjektistrategioita Sibeliuksen Kyllikissä." Musiikki 31/3-4: 5-50.

. 2003. "Sibelius's Kyllikki: Jouissance, Mourning, Melancholy." Sibelius Forum II. Proceedings from the Third International Jean Sibelius Conference (Helsinki, 7-10 December 2000), ed. Matti Huttunen, Kari Kilpeläinen, and Veijo Murtomäki. Helsinki: Sibelius Academy, 303-15. Vaughan, Henry 1963. Poetry and Selected Prose. London: Oxford University Press.

ABSTRACT

The article studies miniatures in Kaija Saariaho's Lichtbogen for nine musicians and live electronics (1985-86). The research material consists of records, the score and composer's interviews and articles. Methodologically, the article is based on Gaston Bachelard's phenomenology (The Poetics of Space) and Denis Smalley's “Spectromorphology." Miniatures are subtle spatio-temporal constellations, which require a non-global listening strategy, or an "aural magnification glass" in order to be perceived. In Saariaho's case, these mini- 
atures are often imbued with musical tension, which reverberates across the material borders of music and texts. By working on the borderline between music and language, they challenge the notion that a hard separation exists between the purely musical and the extra-musical.

\section{RÉSUMÉ}

Cet article étudie les miniatures dans le Lichtbogen de Kaija Saariaho, pour neuf musiciens et électronique en direct (1985-86). Le matériel utilisé pour la recherche est composé d'enregistrements, de la partition, d'entretiens avec la compositeure et différents articles portant sur l'œuvre et sa périphérie. Du point de vue méthodologique, cette recherche s'articule autour de la phénoménologie de Bachelard (La Poétique de l'espace) et de la "spectromorphologie " de Denis Smalley. Les miniatures sont de subtiles constellations spatio-temporelles qui exigent une stratégie d'écoute non globale ou une "loupe auditive " afin de bien les percevoir. Dans le cas de Saariaho, ces miniatures sont souvent imprégnées d'une tension musicale qui se réfléte dans l'ensemble des matériaux musicaux et textuels. En évoluant à la frontière de la musique et du langage, elles remettent en question la notion de séparation stricte entre le musical " pur » et l'extra musical. 